\title{
Design and Analysis of Remote Operated Water Bodies Cleaning Machine
}

\author{
Harikrishnan K M ${ }^{1}$, Livin Tom ${ }^{1}$, Mohammed Fahim P H ${ }^{1}$, Muhammed Shameer A A ${ }^{1}$, Rinto K Anto ${ }^{2}$ \\ ${ }^{1}$ UG Students: Mechanical Engineering Department \\ ${ }^{2}$ Assistant Professor: Mechanical Engineering Department \\ ${ }^{1,2}$ IES College of Engineering Thrissur, Kerala, India
}

\begin{abstract}
This project demanded to clean the water debris by reducing the man work and time consumption using the electronic embedded system. Mainly project pointed to easy handling and eco-friendly machine. The collected wastage can be used in recycle platforms. The project aimed is mainly to seventy percentage of impurities cleaned in water bodies by this project.
\end{abstract}

Keywords:- blue tooth RF control, cutter, conveyor belt, DC motor, recycle.

\section{INTRODUCTION}

Water resources are a large energy resource on earth. It spoiled by wastages, pollutants, litters of sewages and toxic materials etc. water resources can maintained by cleanly is a responsible in human life's, because of humans are more depends on the water bodies.

The "water bodies cleaning machines "are used for collecting on stream water debris by using water turbine and a conveyor belt mechanism. In a world the plastic waste on water bodies is the dangerous issue attained. This project aimed to reduce this problems permanently. Ultimately it will help to decrease water pollution and aquatic animal's death in water. It will used in ponds, streams, lakes and dams etc...

This project aimed to improvise water quality like dams, ponds and other water resources. It is a best solution in treatment of water wastages in homes, production industries, commercial activities and different industries. It is simple treatment process like filtration on water resources. This project is an asset in society clean up sector or departments.

\section{EXPERIMENTAL WORKING}

The main objective of this machine is to reduce water pollution and to save the water bodies surroundings. The working of this machine is similar to a lawn mower. In this machine moves in water bodies and collect all the floating garbage and debris and plastics materials like bottles and covers etc. It is mainly consists of a water wheel (impeller), cutter, conveyor belt, Bluetooth RF controller. The polyvinyl chloride pipes helps to float the machine it's both ends are closed by end caps. The power is supplied with a rechargeable battery and is recharged with solar energy so the solar energy makes it eco-friendly. When the motor rotates it also rotates the spur gear and the pinion helps to reduce the speed of the shaft.

The two shaft are placed at a distance with inclined shape and conveyor belt is mounted on them for the easily transferring of the debris, the inclined shape of the conveyor help the machine touch the slightly below the water level. To reduce the friction the both shafts are fixed in a pair of two bearings. The debris are collected in a tray. Also a cutter is used to cut the roots of the plants. The forward and backward motion of the machine is controlled by an electronic communication circuit. Water wheel or impeller is helps for the movement of machine, by a wiper motor.

To control the machine remotely an RF transmitter and receiver used for all electrical devices.

There are mainly five systems:

1. Floating mechanism

2. Moving mechanism

3. Cutting mechanism

4. Electronic embedded system

5. Solar energy power

\section{$>$ Floating Mechanism}

As the name implies the mechanism used for floating the machine. There are so many floating materials are available. But here used very cheapest method for floating mechanism. Two PVC pipes both ends are closed is used.

\section{Moving Mechanism}

There is two movement in this machine. Movement of machine and movement of conveyor belt.

\section{$>$ Cutting Mechanism}

In water bodies there is some plants that can be seen on the water surface. The roots of these plants reaches the bottom of the water bodies. This will cause block in the path or stack in these plants .So remove this a cutting mechanism is involved.

\section{Electronic Embedded System}

An electronic circuit is used in this machine to control the movement of the machine in a remote. This will help the men's to prevent them from entering the water bodies 


\section{Solar Energy Power}

This machine is eco-friendly, so use renewable energy source for the working of this machine, and uses solar panel and rechargeable batteries.

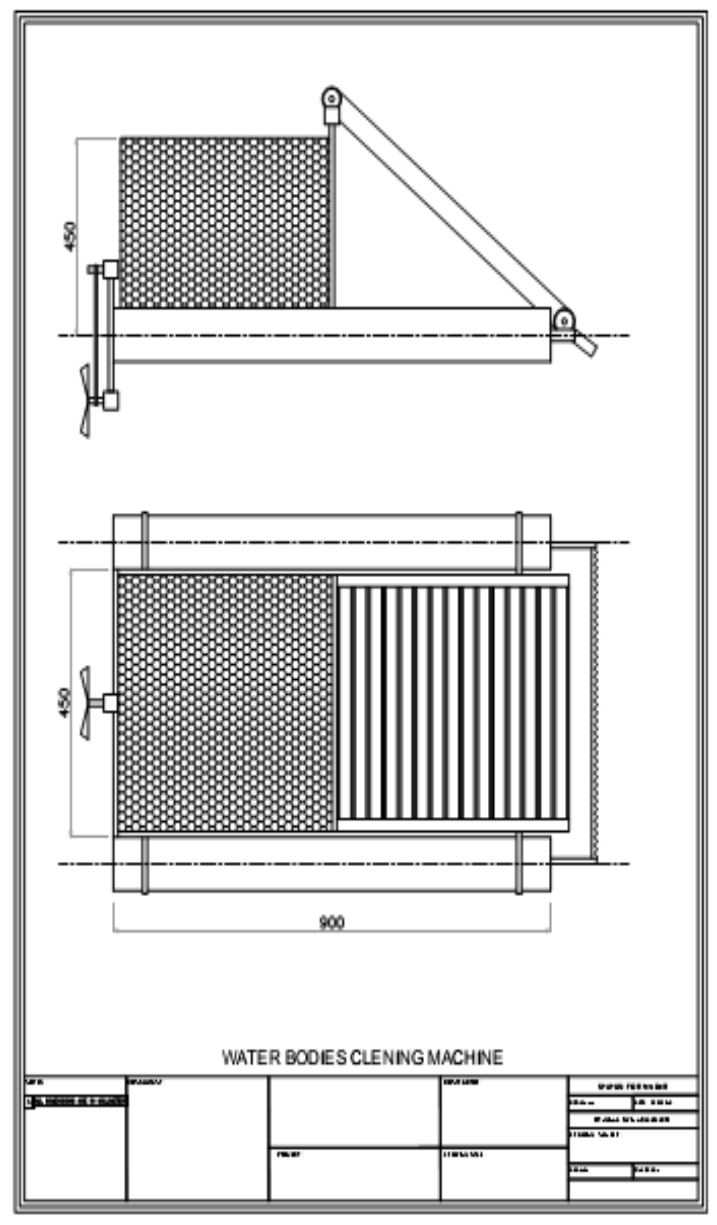

Fig 1:- Orthographic view of remote operated water bodies cleaning machine

\section{SPECIFICATION}

\section{Frame Details (Base)}

Span Length $=900 \mathrm{~mm}$

Breadth $=450 \mathrm{~mm}$

$20 \mathrm{~mm}$ Square pipes

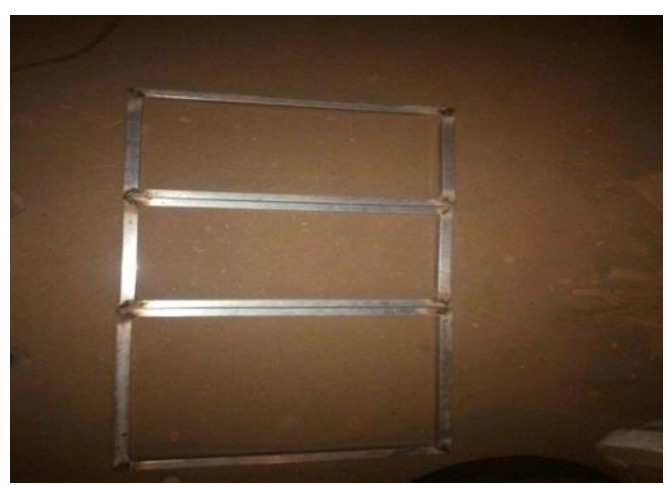

Fig 2:- Base frame

\section{Motor support}

Fixed at $550 \mathrm{~mm}$ from base frame

$>$ Main shaft

Diameter $=32 \mathrm{~mm}$

$>$ Water wheel (turbine)

Diameter $=160 \mathrm{~mm}$

\section{CALCULATION}

Motor Power calculation

Direct Current motor (DC)

Power $=\mathrm{V} * \mathrm{I}$

$\mathrm{V}=12 \mathrm{~V} ; \mathrm{I}=7.6 \mathrm{~A}$

$\mathrm{P}=12 * 7.6=91.2$ watt

Load calculation

Power of motor $=91.2$ watts

Speed of motor $=6000$ RPM

Number of teeth in spur gear $=100$

Effective output speed $=6000 / 100$

$$
=60 \text { RPM }
$$

Torque developed $\left(\mathrm{M}_{\mathrm{t}}\right)=\mathrm{p} / 2 \pi$

$=14.149 \mathrm{Nm}$

Diameter of power screw $=12 \mathrm{~mm}$

Weight that can be lifted $=p / \tan (\theta+\alpha)$

$=739.95 \mathrm{~N}$

$=75.408 \mathrm{Kg}$

\section{DESIGN OF STRAIGHT CUT GEAR \\ (SPUR GEAR)}

(Design of machine element data book K Mahadevan)

$>$ Power transmitting of spur gear

$\mathrm{P}_{\mathrm{S}}=\mathrm{P} * \mathrm{C}_{\mathrm{S}}$

$\mathrm{C}_{\mathrm{S}}=1.5$ for medium shocks ( 8 to 10 hours per day)

Ps $=91.2 * 1.5=136.8$ watts

$$
\text { Module }(\mathrm{m})=\left\{2 \mathrm{Mt} / \sigma_{\mathrm{d}} \mathrm{C}_{\mathrm{v}} \mathrm{k} \pi \mathrm{y} \mathrm{Z} \mathrm{Z}_{\mathrm{p}}^{1 / 3}\right.
$$

Where;

$\sigma_{\mathrm{d}}=220 \mathrm{Mpa}$ Forged steel about $0.30 \% \mathrm{C}$

(heat treated) $; \mathrm{BHN}=200$

(same material for gear and pinion so design based on pinion.)

Pitch line velocity, $v=7 \mathrm{~m} / \mathrm{s}$ ( $\mathrm{v}$ up to $8 \mathrm{~m} / \mathrm{s}$, Barth's formula)

$\mathrm{Cv}=(3.05 / 3.05+7)=0.30$

$\mathrm{k}=\mathrm{b} / \mathrm{m}=10$ (assume)

$\mathrm{b}=$ Face breadth $=10 \mathrm{~m}$

$\mathrm{m}=\{28298 / 220 * 0.3 * 10 * \pi * 0.107 * 24\}^{1 / 3}$

$\mathrm{m}=1.7=2 \mathrm{~mm}$ (standard module)

therefore $\mathrm{dp}=\mathrm{m} \mathrm{Z} \mathrm{Z}_{\mathrm{P}}=2 * 24=48 \mathrm{~mm}$

$>$ Tangential force $\mathrm{F}_{\mathrm{t}}=2 \mathrm{M}_{\mathrm{t}} / \mathrm{dp}$

$\mathrm{F}_{\mathrm{t}}=28298 / 48=589.54 \mathrm{~N}$

By Lewis equation Bending Strength of tooth $F_{b}=\sigma_{d} *$ $\mathrm{C}_{\mathrm{v}} * \mathrm{~b} * \pi \mathrm{y} * \mathrm{~m}$ 
Lewis form factor (table 12.5 Page No. 232) 20o full depth $\mathrm{Z}_{\mathrm{p}}=24$ teeth for pinion,

Therefore, $\mathrm{yp}=0.107$

$\mathrm{Z}_{\mathrm{g}}=100$ teeth for gear,

therefore, $y g=0.142$

$\mathrm{F}_{\mathrm{b}}=\sigma_{\mathrm{d}} * \mathrm{C}_{\mathrm{v}} * \mathrm{~b} * 3.14 * \mathrm{y} * \mathrm{~m}$,

$\mathrm{F}_{\mathrm{b}}=220 * 0.3 * 20 * 3.14 * 0.107 * 2$

$\mathrm{F}_{\mathrm{b}}=886.98 \mathrm{~N}$

$\mathrm{D}_{\mathrm{g}}=118 \mathrm{~mm}$

$\mathrm{F}_{\mathrm{t}}<\mathrm{F}_{\mathrm{b}}$

Design is Safe

(Buckingham Equation) Dynamic load

$F_{d}=\frac{K_{3}}{\left.K_{3} v+\sqrt{(C b}+F_{t}\right)}+F_{t}$

$\mathrm{v}=7 \mathrm{~m} / \mathrm{s}$

Where,

$\mathrm{C}=$ Dynamic Factor,

$\mathrm{C}=780.6 \mathrm{~N} / \mathrm{mm}-\left(20^{\circ}\right.$ full depth $)$

$\mathrm{K}_{3}=20.67$ SI Unit

$\mathrm{F}_{\mathrm{d}}=20.67 * 7(780.6 * 20+589.54)+589.54$

$20.67 * 7+\sqrt{(780.6 * 20+589.54)}$

$\mathrm{F}_{\mathrm{d}}=920.7 \mathrm{~N}$

$\mathrm{F}_{\mathrm{d}}>\mathrm{F}_{\mathrm{t}}$

Design is safe

Limiting load for wear strength

$\mathrm{F}_{\mathrm{w}}=\mathrm{D}_{\mathrm{p}} * \mathrm{Q} * \mathrm{k} * \mathrm{~b}$

$\mathrm{Q}=2 \mathrm{Z}_{\mathrm{g}} / \mathrm{Z}_{\mathrm{g}}+\mathrm{Z}_{\mathrm{p}}$

$\mathrm{Q}=2 \times 100 / 100+24$

$\mathrm{Q}=1.61$

$\mathrm{k}=0.539$ (table 12.16)

$\mathrm{F}_{\mathrm{w}}=48 * 1.61 * 0.539 * 20$

$\mathrm{F}_{\mathrm{w}}=1041.348 \mathrm{~N}$

$F_{d}<F_{w}$

Design is safe

Beam Strength (Endurance)

$\mathrm{F}_{\mathrm{en}}=\sigma_{\mathrm{en}} * \mathrm{~b} * \mathrm{Y} * \mathrm{~m}$

Where, $\sigma_{\mathrm{eb}}=345 \mathrm{Mpa}$, (table 12.15)

$\mathrm{Y}=\pi * 0.107$

$\mathrm{b}=20 \mathrm{~mm}, \quad \mathrm{~m}=2$

$\mathrm{F}_{\mathrm{en}}=345 * 20 * \pi * 0.107 * 2$

$\mathrm{F}_{\mathrm{en}}=4638.8 \mathrm{~N}$

$F_{\text {en }}>F_{d}$

Design is safe

\section{CONSTRUCTIONAL PROCEDURE}

$>$ The base frame is made up of $20 \mathrm{~mm} * 20 \mathrm{~mm}$ square pipe and jointed by welding process.

$>$ Two poly vinyl chloride (pvc) pipes are used for the floating mechanism and both ends are closed by end caps. These pipes are mounted on the base frame with help of U-clamps. These U-clamps are welded on the base frame and pipes are mounted by wire strips.

$>$ From a height of $550 \mathrm{~mm}$ from base frame motor is mounted with the help of bolts and nuts.

$>$ One shaft is mounted on the DC motor with spur gear and pinion to reduce the speed of shaft and to increase torque with the help of bearings.
Another shaft is mounted on the front of base 4 frame where the conveyor belt is fixed between these two shafts. The conveyor belt is used to transfer wastes from the water bodies.

$>$ These wastes are collected on the tray, that is mounted on the base frame behind shaft and motor. When the tray is filled with debris these takes from the tray and goes to disposal.

$>$ A cutter is fixed a small distance below the base frame to cut the roots of the plants. The cutter is mounted on the front side of the base frame the power for this cutter is supplied with a DC motor.

$>$ A water wheel (turbine) is used to move forward and back ward motion of the machine. This water wheel mounted on the back of the base frame from a short distance below from it.

$>$ The to and fro motion of the machine is controlled by a Bluetooth RF controller which helps to control the motion with a remote.

$>$ There should be a platform for mounting the controlling circuit and for the battery these are fixed with screw and clamps.

$>$ Also a solar panel is mounted above these circuit for recharging the batteries.

\section{DVANTAGES}

This is environmental friendly, because it uses renewable energy for recharging their batteries.

$>$ By using this only one men is required to control the operation, so it reduces man power and problems caused by traditional cleaning process.

> It does not requires skilled operators, anyone can control : so it is flexible.

\section{DISADVANTAGES}

Waste collecting capacity is limited.

$>$ Load carrying capacity is low.

$>$ Cutter requires more power.

\section{FUTURE SCOPE}

Using of latest floating material.

$>$ Using thermal sensors.

$>$ Long distance controlling

$>$ Liquid waste dilution.

\section{CONCLUSION}

The analysis that is done on the project helps to reach this project a socially relevant one, it helps the society by using renewable energy for it does not causes pollution.

The main objective of this project is to reduce the mental stresses faced by society on their polluted water bodies and to save environment from pollutions. By this project the goals was fortunately attained. 


\section{REFERENCES}

[1]. R S Khurmi, - textbook of - "Fluid mechanics and machinery"

[2]. R S Khurmi - textbook of - "Machine design".

[3]. R S Khurmi - textbook of -"Strength of Materials".

[4]. K Mahadevan - textbook of - "Design of machine element"

[5]. R K Bansal - textbook of -"fluid mechanics and machinery"

[6]. K Mahadevan, data book -“design of machine element"

[7]. P S G data book - "design of machine element". 